
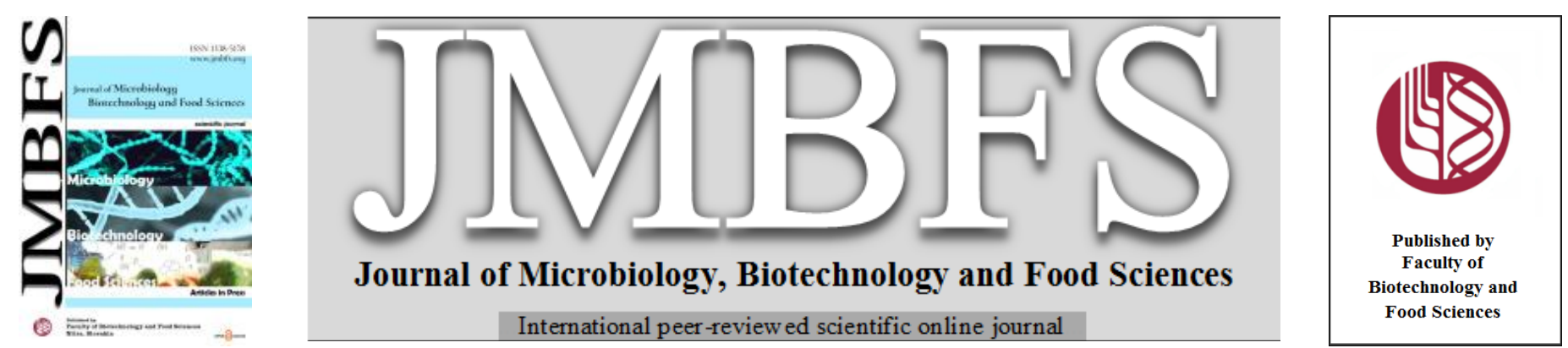

\title{
FUNGAL AND BACTERIAL RHIZOSPHERE MICROBIOME ASSOCIATED WITH SELECTED MELON AND SNAKE MELON GENOTYPES
}

\author{
Rania Aydi-Ben-Abdallah ${ }^{* 1}$, Hela Chikh-Rouhou ${ }^{1}$,Hayfa Jabnoun-Khiareddine ${ }^{1}$, Rafika Sta-Baba $^{2}$, Mejda Daami-Remadi $^{1}$
}

Address(es): Dr. Rania Aydi-Ben-Abdallah,

${ }^{1}$ LR21AGR03-Production and Protection for a Sustainable Horticulture, University of Sousse, Regional Research Centre on Horticulture and Organic Agriculture, BO. 57, 4042, Chott-Mariem, Tunisia.

${ }^{2}$ Regional Research Centre on Horticulture and Organic Agriculture, University of Sousse, 4042, Chott-Mariem, Tunisia.

*Corresponding author: raniaaydi@yahoo.fr

https://doi.org/10.15414/jmbfs.4004

\section{ARTICLE INFO}

Received 25. 11. 2020

Revised 17. 6. 2021

Accepted 29. 6. 2021

Published 1. 12. 2021

Regular article

OPEN $\partial_{\text {ACCESS }}$

\begin{abstract}
The composition of rhizospheric microbial community may be shaped by plant genotype. Forty five melon (Cucumis melo L.) and seven snake melon (Cucumis melo var. flexuosus) genotypes were tested for their growth and yield parameters compared to a commercial melon cultivar "Star plus". To estimate the microbial community in the rhizospheric soil of these genotypes, soil dilution plating technique on specific agar medium was used and compared to control. The majority of melon genotypes showed significantly comparable height, fruit weight and fruit yield per plant as "Star plus". The fruit yield per plant varied significantly depending on tested genotypes. The total bacterial population in the rhizosphere of ten melon and two snake melon genotypes was significantly 59 to $68 \%$ higher than control soil. For most tested genotypes, a significant increase in the culturable rhizospheric actinomycetes, about 28.5 to $92.6 \%$, was recorded comparatively to control soil. Fungal population counts in the rhizosphere of tested genotypes were significantly comparable to control. The genotypic difference in melon and snake melon reflects the quantum and diversity of their microbiomes that melon breeders could benefit when seeking at the holobiont concept to include associated microbiomes in breeding programs.
\end{abstract}

Keywords: Breeding, Cucumis melo L., Fruit yield, Genotype, Soil microbial community

\section{INTRODUCTION}

The plant microbiome has been known to be one of the key determinants of plant health and productivity for more than a Century. Plant-associated microbiomes confer fitness advantages to the plant host, including growth promotion, nutrient uptake, stress tolerance and resistance to pathogens (Trivedi $\boldsymbol{e t}$ al., 2020). Hence, the distribution of soil microbial community was highly affected by various environmental factors, agricultural management, soil characteristics, and plant species interactions (Compant et al., 2019). The interaction between soil microbial structure and genotypes of the same plant species is a key factor for plant breeders aiming to incorporate associated microbiomes in breeding plan. Indeed, within each species, plant genotype may also affect rhizosphere community composition (Carelli et al., 2000). These effects are likely attributed to the differences in the root cell components and to the chemical composition of their exudates (Merbach et al., 1999). Root exudates represent an important component of communication with rhizosphere-inhabiting microorganisms (Haichar et al., 2014). They mainly determine the composition of the rhizospheric microbial community and the soil microbial pool as they depend on plant species, genotype and fertilization regime (Rengel and Marschner, 2005; Appuhn and Joergensen, 2006; Aira et al., 2010). According to Wissuwa et al. (2008), plant host genetic traits play a significant role in the selection of root-associated microbial communities. The limited taxonomy of plant-associated microbes, compared with the extensive diversity of soil microorganisms, suggests that plants exert a highly selective pressure on microbial niche (Finkel et al., 2017). This selection has important implications for plant health and growth since rhizospheric microorganisms are known to have positive or negative effects. As for their beneficial effects, these may include growth promotion, protection against pathogenic agents, carbon sequestration, and phytoremediation (Nallanchakravarthula et al., 2014). Soil characteristics as well as plant genotypes shaped the microbial community structure in the rhizosphere (Bulgarelli et al., 2012). In fact, within genotypes, the variability of the microbial community in the rhizosphere is involved in their variable responses to diseases (Nallanchakravarthula et al., 2014). Plants may employ plant-beneficial microbes associated to their roots to respond to some biotic and abiotic stresses The impact of the root microbiome on plant health is evidenced most clearly in disease-suppressive soils (Berendsen et al., 2012).

Melon (Cucumis melo L.) is a widely consumed fruit, able to produce a wide variety of biologically active compounds such as vitamins $\mathrm{C}$, pro-vitamin $\mathrm{A}$, folic acid, phenolic phytochemicals, and antioxydants. For melons, the levels of these bioactive substances vary extensively depending on genotype and environmental conditions during production and post-harvest manipulation (Vanoli et al., 2015) In addition, it has been also shown that soil microorganisms are indirectly involved in the determination of fruit quality (Reganold et al., 2010).

Technological advances, coupled with a need for sustainable crop yield enhancement, have reinvigorated the study of beneficial plant-microbe interactions with emphasis on how microbiomes alter plant phenotypes (Finkel et al., 2017) Some of the melon and snake melon genotypes tested in the present study were obtained from the melon breeding programs aiming the development of efficient hybrids (Chikh-Rouhou et al., 2017) showing resistance to Fusarium oxysporum f. sp. melonis (Chikh-Rouhou et al., 2018) and good fruit quality (Chikh-Rouhou et al., 2021). Plant breeding using beneficial plant-microbe interactions is a promising field focused principally on the below ground interactions in the rhizosphere (Bakker et al., 2012). Since more than a century, diversity and function of the rhizosphere microbiome was heavily studied and the effect of plant genotype and soil quality was established (Bergand and Smalla, 2009). Recent researches on crop cultivars revealed that breeding shapes the composition of the root-associated bacterial communities including their antagonistic potential towards pathogens (Cardinale $\boldsymbol{e t}$ al., 2015). Genotype-specific beneficial plantmicrobe associations have not been considered in breeding strategies thus far (Adam et al., 2018). The knowledge of the rhizosphere microbiome, offering genetic variability to plants, opens up new horizons for plant breeding that could usher in cultivation of next-generation crops depending less on inorganic inputs, resistant to diseases and resilient to climatic changes (Gopal and Gupta, 2016). Plant-associated microbiota plays a fundamental role in the regulation of plant physiology and affects a range of traits involved in plant yield by regulating growth hormone balance, stimulating plant immunity and enhancing nutrient uptake. 
Hence, plant-microbe interactions can generate a range of new phenotypes without altering plant genomic information (Wei and Jousset, 2017). In view of previous findings (Marques et al., 2014; Edwards et al., 2015; Gopal and Gupta 2016; Wille et al., 2018), focus will be on complementary breeding strategy based on genotypes holobiont which microbes are one of the direct targets of the selection process that help achieve a desired plant phenotype. The current study is a first step to gain deeper understanding of an eventual link between some melon and snake melon genotypes, their associated soil microorganisms and their growth and yield parameters. The main objective is the development of a concept to re-integrate beneficial plant-microbe interactions into the further melon and snake melon breeding strategy. This complementary plant breeding approach is a nove technology that will help reaching novel phenotypes.

\section{MATERIALS AND METHODS}

\section{Plant material}

Forty five melon (Cucumis melo L.) and seven snake melon (Cucumis melo var. flexuosus) genotypes were used in this study. They were selected from the Cucumis melo breeding program conducted in the Regional Research Centre on Horticulture and Organic Agriculture (CRRHAB), Tunisia; some of them showed heterosis for fruit characters and yield component (Chikh-Rouhou et al., 2017) and their parents were resistant to Fusarium oxysporum f. sp. melonis races 1 and 2 (ChikhRouhou et al., 2018). A commercial melon cultivar "Star plus" was used as control.

For each genotype, seeds were sown in cell trays and maintained at $25^{\circ} \mathrm{C}$ under greenhouse conditions. At the two-true-leaf growth stage, they were further transplanted to an experimental greenhouse located at Monastir, Tunisia (N35 46'40", E1049'34").

\section{Experimental design}

Melon seedlings were transplanted into rows with a distance of $40 \mathrm{~cm}$ between seedlings within the same row and $80 \mathrm{~cm}$ between rows. The experimental design was a completely randomized block design. Two replicates were used per genotype; each replication consisted of six seedlings per genotype. They were subjected to agricultural practices commonly adopted by farmers in the region and irrigated and fertilized as needed.

\section{Soil sampling}

Composite soil samples from each individual plot were collected thrice i.e. before planting, at the fruit stage, and two weeks after harvest. At the fruit stage, three soil cores $(7 \mathrm{~cm}$ in diameter $\times 15 \mathrm{~cm}$ in depth) were removed and combined to make one composite soil per genotype. At initial and final stages, ten soil cores were removed at each sampling date and were combined to make one composite soil Two replicates were considered for each soil sampling.

Once brought to laboratory, soil samples were passed through a 2-mm sieve to remove rocks and large organic debris. They were stored in plastic bags at $10^{\circ} \mathrm{C}$ and processed within one week after sampling (Larkin and Honeycutt, 2006). For further assays, two subsamples were processed from each soil sample.

\section{Estimation of soil microbial community}

General populations of culturable soil microorganisms were determined using the soil dilution plating techniques on various agar media according to Larkin and Honeycutt (2006) with some modifications. For each subsample taken from each composite soil, $10 \mathrm{~g}$ were added to $90 \mathrm{ml}$ of sterile $0.2 \%$ water agar, vigorously stirred for $30 \mathrm{~min}$, serially diluted and a-100 $\mu 1$ sample was plated on $10 \%$ Tryptic Soy Agar (TSA) for total bacterial counts, selective King's B medium (KB) amended with $75 \mathrm{mg} \mathrm{l}^{-1}$ of penicillin and $75 \mathrm{mg} \mathrm{l}^{-1}$ of cyclohexamide for Pseudomonas fluorescens counts, Yeast Malt Agar (ISP medium No. 2) amended with $75 \mathrm{mg} \mathrm{l}^{-1}$ of nalidixic acid and $100 \mathrm{mg} \mathrm{l}^{-1}$ of cyclohexamide for actinomycete counts, and Potato Dextrose Agar (PDA) amended with $300 \mathrm{mg} \mathrm{l}^{-1}$ of streptomycin sulphate for total fungal counts. Three replicates of one plate each were used for each soil subsample.

Bacterial and actinomycete plates were incubated at $28^{\circ} \mathrm{C}$ for 2 and 14 days, respectively, and fungal plates were maintained at $25^{\circ} \mathrm{C}$ for 7 days. Colonies of Trichoderma spp., Aspergillus spp., Penicillium spp., and Fusarium spp. were identified based on their macro- and micro-morphological traits (Barnett and Hunter, 1987) under light microscope and counted separately. The soil microbial population count was estimated per $1 \mathrm{~g}$ of fresh soil.

\section{Growth and yield parameters}

At harvest (five months after planting), the average fruits weight produced per plant was determined by dividing the total weight of all harvested fruits by the total number of plants. The average yield per plant was noted at the last harvest. The plant height was determined at three months post-planting for three randomly sampled plants.

\section{Statistical analysis}

Data were subjected to a one-way analysis of variance (ANOVA) using Statistica Package for the Social Sciences (SPSS) software for Windows version 16.0. Data were analyzed according to a completely randomized block design. Experiments were repeated twice. Means were separated using Student-Newman-Keuls tests to identify significant pair-wise differences at $P \leq 0.05$. Data analyses for the microbial community count at the initial stage (before planting) and at the final stage (two weeks after harvest) were performed with t-test at $P \leq 0.05$. Correlations between growth and yield parameters and microbial community structure were carried out using bivariate Pearson's test at $P \leq 0.05$.

\section{RESULTS}

\section{Microbial community structure}

\section{Bacterial population}

Analysis of variance revealed that, at the fruiting stage, the number of bacterial colonies growing from plated soil samples, noted after 2 days of incubation on TSA medium, varied significantly (at $P \leq 0.05$ ) upon tested melon and snake melon genotypes. In fact, as compared to "Star plus", a significant improvement, of abou 59.9 to $68.4 \%$, was recorded in the total culturable bacterial community isolated from the rhizospheric soil of 10 melon genotypes (H0, H3, H5, H7, H11, H19, $\mathrm{H} 26, \mathrm{H} 32, \mathrm{H} 37$ and $\mathrm{H} 42$ ) and of about $65-66.8 \%$ in that of H46 and H50 snake melon genotypes (figure 1a).

As for the bacterial biodiversity, the relative abundance of Pseudomonas spp. community was found to be relatively important in the rhizosphere of $\mathrm{H} 3, \mathrm{H} 6, \mathrm{H} 7$, $\mathrm{H} 16, \mathrm{H} 24, \mathrm{H} 27, \mathrm{H} 33, \mathrm{H} 36, \mathrm{H} 37, \mathrm{H} 38$ and $\mathrm{H} 45$ melon genotypes and in that of $\mathrm{H} 10$ snake melon genotype which was about three times higher than control (figure 2a). In addition, Pseudomonas fluorescens counts from the soil of $\mathrm{H} 0, \mathrm{H} 4$ and $\mathrm{H} 35$ melon genotypes were $29 \%$ much higher than control. As given in Fig. 2a, soil sampled around most of the tested genotypes showed significant increases, by about 28.5 to $92.6 \%$ over control cultivar, in the total culturable actinomycetes. As given in Tab 1, the total culturable bacteria count, estimated at two weeks post harvest, was three times higher than that noted before planting. Indeed, Pseudomonas spp. and actinomycetes colonies were more abundant at two weeks post-harvest than at the initial stage.

Table 1 Soil ${ }^{\mathrm{x}}$ microbial community estimated at the initial stage (before planting) and at the final stage (two weeks post harvest) as determined by soil dilution ${ }^{y}$ plating on selective media

Total Culturable microbiome ( $\mathrm{CFU}^{*}$ per $1 \mathrm{~g}$ of fresh soil)

\begin{tabular}{lccc}
\hline & Bacteria $\left(\times \mathbf{1 0}^{\mathbf{8}}\right)$ & Actinomycetes $\left(\times \mathbf{1 0}^{\mathbf{4}}\right)$ & Fungi $\left(\times \mathbf{1 0}^{\mathbf{4}}\right)$ \\
\cline { 2 - 4 } Initial stage & $1.7 \mathrm{~b}$ & $0.66 \mathrm{~b}$ & $21 \mathrm{a}$ \\
Final stage & $6.26 \mathrm{a}$ & $8.66 \mathrm{a}$ & $11.66 \mathrm{~b}$ \\
\hline
\end{tabular}

Culturable bacteria populations $\left(\times 10^{4} \mathrm{CFU}\right.$ per $1 \mathrm{~g}$ of fresh soil)

Pseudomonas spp.

Pseudomonas fluorescens

\begin{tabular}{|c|c|c|c|c|}
\hline \multirow{3}{*}{$\begin{array}{l}\text { Initial stage } \\
\text { Final stage }\end{array}$} & \multirow{2}{*}{$0 \mathrm{~b}$} & & \multicolumn{2}{|c|}{ - } \\
\hline & & & \multicolumn{2}{|c|}{0} \\
\hline & $16.66 \mathrm{a}$ & & & \\
\hline & \multicolumn{4}{|c|}{ Culturable fungi populations $\left(\times 10^{4} \mathrm{CFU}\right.$ per $1 \mathrm{~g}$ of fresh soil $)$} \\
\hline & Aspergillus spp. & Penicillium spp. & Trichoderma spp. & Fusarium spp. \\
\hline Initial stage & $11 \mathrm{a}$ & $0 \mathrm{~b}$ & $0 \mathrm{a}$ & $2.3 \mathrm{a}$ \\
\hline Final stage & $4 \mathrm{~b}$ & $2.6 \mathrm{a}$ & $0.33 \mathrm{a}$ & $0 \mathrm{~b}$ \\
\hline
\end{tabular}




\section{Fungal population}

Legend: Values followed by the same letter are not significantly different according to t-test at $P \leq 0.05$.

${ }^{\mathrm{x}}$ Composite soil from ten soil cores collected at each sampling stage.

Dilution was made from a concentration of $10 \%\left(\mathrm{w} \mathrm{v}^{-1}\right)$.

Colony-Forming Unit

The total number of culturable fungal colonies, estimated at the fruiting stage in the rhizosphere of tested melon and snake melon genotypes, was significantly similar as control except for melon genotype H37 which was three times higher than that of "Star plus" (figure 1b).

Aspergillus spp. colonies were 36.8 and $53.8 \%$ more abundant in the rhizosphere of $\mathrm{H} 50$ and $\mathrm{H} 49$ snake melon genotypes, respectively, than in control soil samples (figure 2b). Soil samples from rhizosphere of H0, H11, H13, H20, H44, H45 and H46 genotypes was three and six times more rich in Penicillium spp. colonies than control. As for Trichoderma spp. population, the rhizosphere of 10 melon (namely $\mathrm{H} 14, \mathrm{H} 18, \mathrm{H} 21, \mathrm{H} 23, \mathrm{H} 32, \mathrm{H} 34, \mathrm{H} 35, \mathrm{H} 37, \mathrm{H} 40$, and H44) and three snake melon genotypes (H10, H49 and H50) showed three to twenty three times more abundance of these fungi as compared to control cultivar (figure 2b). No Fusarium colonies were recovered from the rhizosphere of $\mathrm{H} 0, \mathrm{H} 3, \mathrm{H} 5, \mathrm{H} 7, \mathrm{H} 11, \mathrm{H} 12, \mathrm{H} 14$ H15, H16, H17, H19, H21, H22, H23, H24, H26, H27, H33, H35, H36, H40, H41, $\mathrm{H} 43, \mathrm{H} 44, \mathrm{H} 45, \mathrm{H} 52, \mathrm{H} 46$, and $\mathrm{H} 47$ genotypes as also noted in the rhizosphere of control cultivar "Star plus" (figure 2b).

The total culturable fungal community determined in soil samples collected the final stage was significantly two times less than that noted before planting Penicillium and Trichoderma species were more abundant at the final state than before planting. However, no Fusarium spp. colonies were recovered from soil samples removed two weeks post-harvest (Tab 1).

(a)
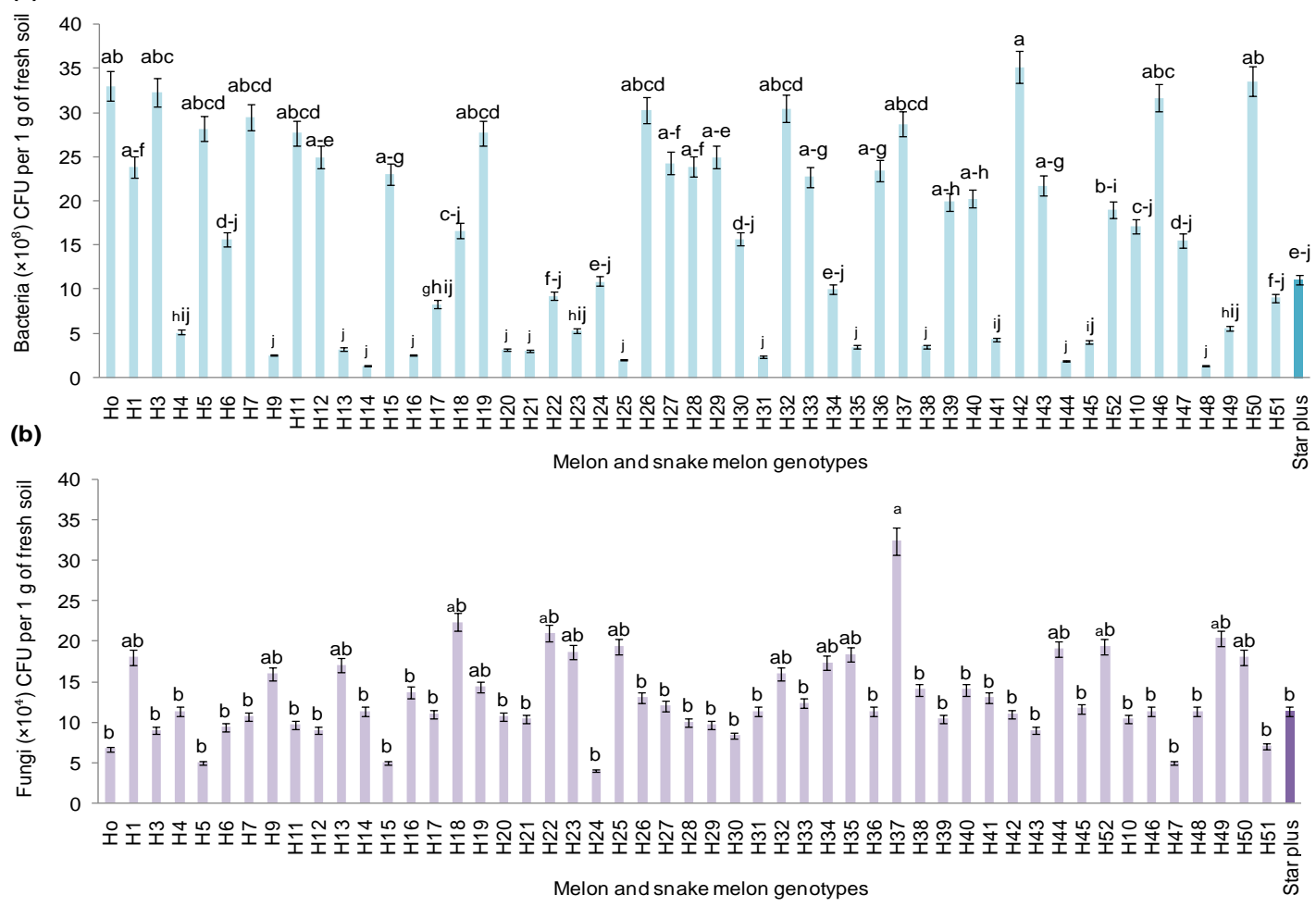

Figure 1 Variation of total culturable bacteria and fungi on the rhizosphere of different melon and snake melon genotypes, at the fruit stage, compared to a commercial melon cultivar "Star plus", as determined by soil dilution" plating on selective media

Legend: H0 to H7, H9, H1 1 to H45 and H52: Melon genotypes; H10, H46, H47, H48, H49, H50 and H51: Snake melon genotypes. Results are presented as mean \pm Standard error (SE) (number of replication $(\mathrm{n})=6, P \leq 0.05)$; ${ }^{\mathrm{y}}$ Dilution was made from a concentration of $10 \%\left(\mathrm{w} \mathrm{v}^{-1}\right)$. Bars sharing the same letter are not significantly different according to Student Newman Keuls test at $P \leq 0.05$ 


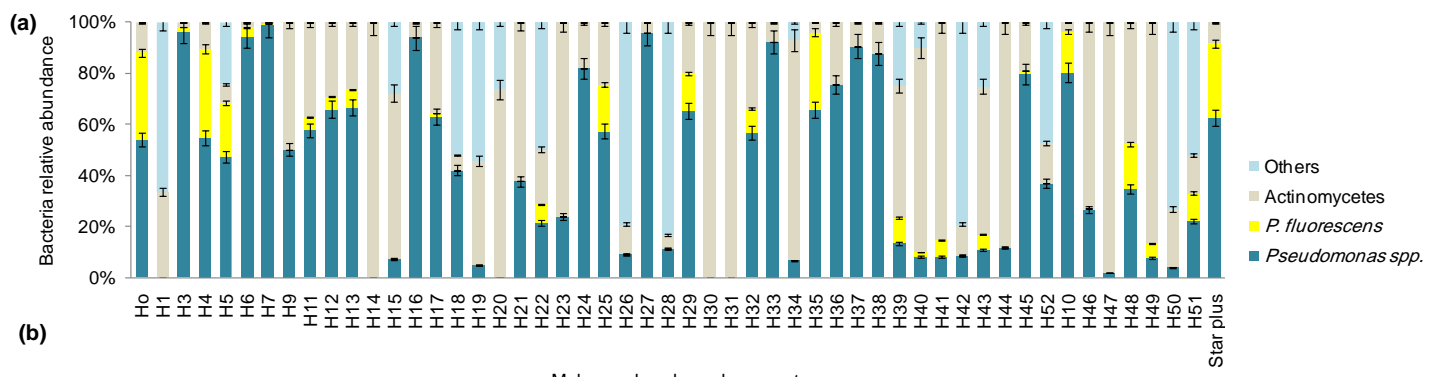

Melon and snake melon genotypes

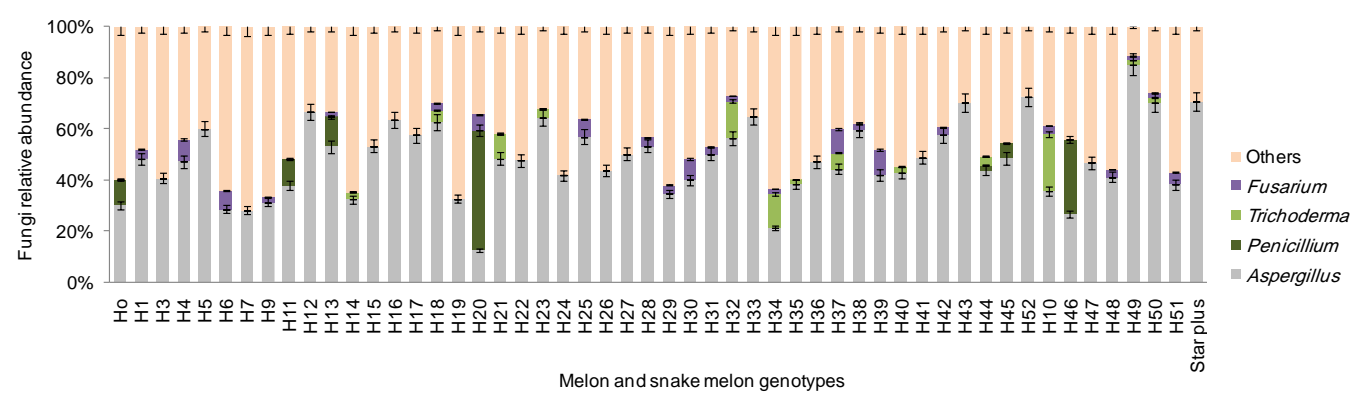

Figure 2 Relative abundance of the rhizosphere microbial community structure of melon and snake melon genotypes, at the fruit stage, compared to a commercialized melon cultivar "Star plus"

Legend: H0 to H7, H9, H11 to H45 and H52: Melon genotypes; H10, H46, H47, H48, H49, H50 and H51: Snake melon genotypes. Results are presented as mean \pm SE (n = 6, P $\leq 0.05$ ). The relative abundance was estimated per the total bacteria and fungi counted in each sampled soil.

Melon and snake melon growth, production and yield

\section{Plant height}

The plant height, noted three months post-planting, varied significantly (at $P \leq$ 0.05 ) upon melon genotypes. As illustrated in figure 3a, expect $\mathrm{H} 18, \mathrm{H} 24$, for $\mathrm{H} 29$ to $\mathrm{H} 32$ and $\mathrm{H} 34$ to $\mathrm{H} 40$ and $\mathrm{H} 44$, all remaining genotypes showed significantly comparable height as the commercial melon cultivar "Star plus". Increment, of about 0.8 to $25.6 \%$, was noted on 24 genotypes, as compared to control. No significant variation was recorded between snake melon genotypes when assessed for their plant height at three months post-planting (figure $3 b$ ).

\section{Average fruit weight}

Analysis of variance revealed a significant (at $P \leq 0.05$ ) variation of the fruit weight depending on tested genotypes. Data given in figure $3 \mathrm{c}$, revealed that 13 melon genotypes produced fruits of significantly similar weight as the control "Star plus". $\mathrm{H} 34, \mathrm{H} 2, \mathrm{H} 5, \mathrm{H} 45$ and $\mathrm{H} 0$ genotypes showed $2.5-26.4 \%$ higher fruit weight relative to control. However, no significant differences were noted between snake melon genotypes based on this parameter (figure 3d).

\section{Total fruit yield per plant}

The total fruit yield produced per plant varied upon tested melon genotypes (figure $3 e$ ). Eighteen melon genotypes produced significantly similar fruit yield per plant as control. Melon (H41, H13, H52 and H17) genotypes showed 0.1-33.5\% higher fruit yield over control. As shown in figure $3 \mathrm{f}$, the total fruit yield per plant significantly varied depending on snake melon genotypes tested where $\mathrm{H} 47, \mathrm{H} 48$, H49 and H50 produced the highest fruit yield. 


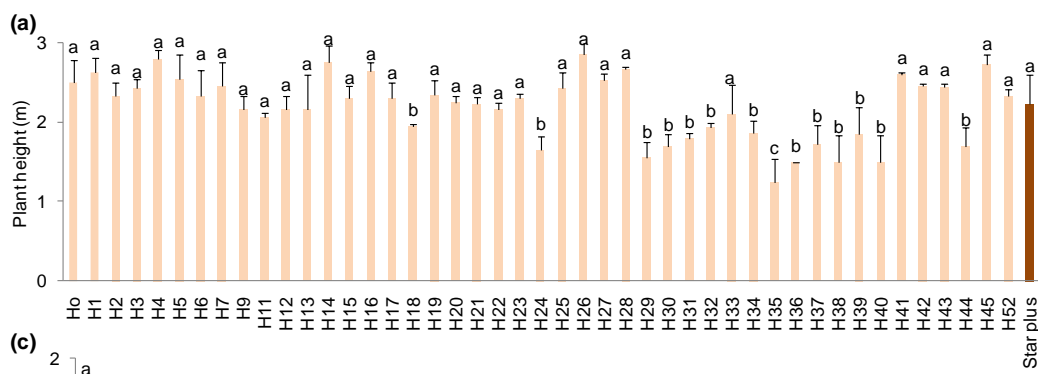

(b)
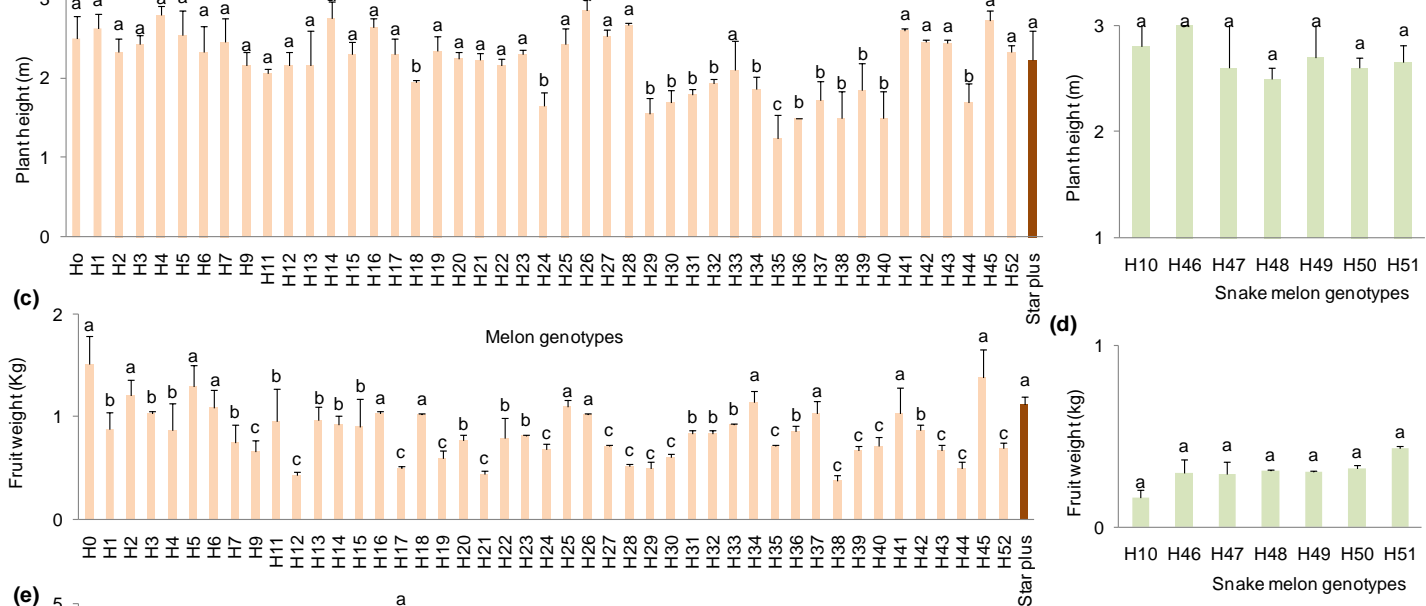

(d)

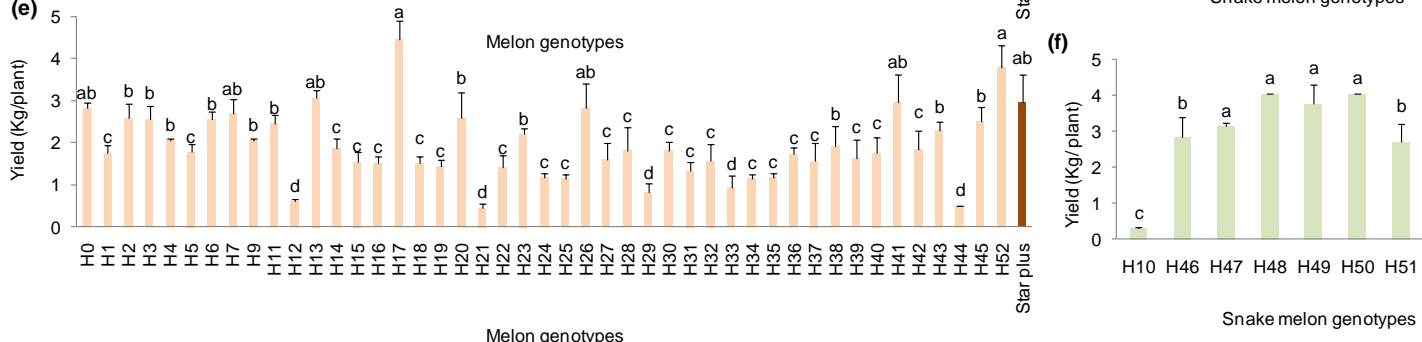

Figure 3 Comparative plant growth and yield of melon and snake melon genotypes compared to the commercial melon cultivar "Star plus" grown under greenhouse condition of the experimental station of Monastir (N35 46'40", E10 $\left.49^{\prime} 34^{\prime \prime}\right)$ for five months

Legend: H0 to H7, H9, H11 to H45 and H52: Melon genotypes; H10, H46, H47, H48, H49, H50 and H51: Snake melon genotypes. Bars sharing the same letter are not significantly different according to Student Newman Keuls test at $P \leq 0.05$. The average fruit weight (c, d) and the average yield (e, f) per plant were determined at harvest. The plant height (a, b) was noted at three months post-planting.

\section{Correlation between growth and yield parameters and microbial community structure}

Pearson's correlation analysis indicated that plant height was significantly and negatively correlated to the total fungal population in the soil $(\mathrm{r}=-0.295, P=$ 0.032 ). The average fruit weight was significantly and positively linked to the presence of Pseudomonas spp. in the analyzed soil samples $(\mathrm{r}=0.292, P=0.036)$ Similar trend was observed between the fruit weight $(\mathrm{r}=0.339, P=0.013)$ and the total fruit yield per plant $(\mathrm{r}=0.380, P=0.005)$ and the relative abundance of actinomycetes in the soils.

\section{DISCUSSION}

Soil microbial diversity can be used as a biomarker for healthy and productive plant. Moreover, combined breeding and biocontrol strategies maintaining diversity and ecosystem health are required. These systemic approaches are required in order to avoid further losses of our biodiversity and to ensure sustainable agricultural practices (Berg et al., 2017).

In the current work, it was clearly showed that tested genotypes had significantly influenced soil microbial community. Plant functional groups, plant species and subtle gradients of plant genetic factors, such as genotypes, are known to shape the soil microbial community structure (Kang and Mills, 2004). Results from the present study showed that the relative abundance of bacteria and fungi varied depending on tested genotypes. Comparable effects were reported in the rhizosphere of different cucumber and wheat cultivars (Diab et al., 2001; Yao and Wu, 2010). Berendsen et al. (2012) affirmed that microbial communities in the rhizosphere vary depending on genotypes, which imply that plants are able to mold their proper rhizospheric microbiome. According to Aira et al. (2010), the different carbon allocation strategies in the different plant genotypes should promote distinct rhizosphere microbial communities. The variation in these communities has been assigned to the differences in the amount and the composition of root exudates and mainly carbon sources which are limiting factors for microbial activity and proliferation (Marschner et al., 2007).

As for bacterial diversity in the rhizosphere of tested genotypes, a significan population of total culturable bacteria, and especially Actinomycetes and Pseudomonas, was associated to most of the tested genotypes compared to control cultivar "Star plus". Bulgarelli et al. (2012) and Lundberg et al. (2012) showed the relative dominance of members of the actinobacteria, Bacteroidetes, and Proteobacteria in rhizosphere communities which are also strongly shaped by soil type and plant genotypes. Some microbes have a particular affinity for certain plan genotypes in determining rhizosphere communities. Weinert et al. (2011) showed differences between three potato cultivars regarding the abundance of their associated microbes, belonging to the Pseudomonales, Streptomycetaceae and Micromonosporaceae, and being widely explored for their ability to control various plant pathogens. These results indicate that the genotype can influence the accumulation of microorganisms that help the plant to defend itself against further pathogen attack. Yao and Wu (2010) suggested that the increase in actinomycetes populations can inhibit the growth of soil-borne pathogens. In addition to their direct effects occurring in the rhizosphere against pathogenic microbes, many beneficial soil-borne microorganisms are involved in the boosting of the defensive capacity even in the above-ground parts of the plant (Zamioudis and Pieterse, 2012).

As for the population of the total culturable fungi estimated in the rhizosphere of tested melon and snake melon genotypes, no significant differences were noted compared to control cultivar. Trichoderma spp. were recovered from soil of some genotypes. Among identified fungi, control soil contains only Aspergillus colonies. Fusarium and Penicillium were associated to few genotypes. Soil-borne Aspergillus, Fusarium, Penicillium may be pathogenic or antagonistic. Usually, soil-borne fungal pathogens were lower in resistant cultivars compared to the susceptible ones (Yao and $\mathbf{W u}, \mathbf{2 0 1 0}$ ). Wu et al. (2006) reported that the root exudates of cucumber resistant cultivars had an adverse effect on soil $F$. oxysporum populations. Breeding program for the selection of Fusarium-resistant genotypes is underway to confirm this investigation.

Penicillium, Aspergillus, and Fusarium populations, estimated in the sampled soils from around melon and snake melon genotypes as well as from control cultivar, may be beneficial microbes having antagonistic potential against phytopathogens. In fact, plants were healthy and did not exhibit any disease symptoms, however, isolation of eventual associated pathogens from plant tissues should be considered in the future together with the assessment of the microbial community structure at the rhizosphere level. Indeed, some potential plant-beneficial microbial could act as network key, thus reducing the chance of plant soil-borne pathogen invasion (Yang et al., 2017). Numerous previous researches have demonstrated the antagonistic activity of non pathogenic Penicillium (Radhakrishnan et al., 2013), Trichoderma (Balasubramanian et al., 2014) and Fusarium species recovered from rhizospheric soils (Aime et al., 2013).

Among the major objectives of the current investigation is to examine the link between the microbial diversity at the rhizosphere level of different melon and snake melon genotypes and its eventual effect on plant growth and fruit yield Results from this study clearly demonstrated a significant and positive correlation between the average fruit weight and the presence of Pseudomonas spp. colonies and between the fruit weight and the total fruit yield per plant and actinomycetes populations in the explored rhizospheric soil samples. As suggested by Cordero and Polz (2014) and Weidner et al. (2015), the diversity of microbial inoculum can amplify available plant-associated niches and improve productivity. Complex 
inocula can improve plant growth (Timm et al., 2016) and disease resistance (Wei et al., 2015) than single strains. Interpreting the effect of microbial and plant diversity on microbiome function must be further done in a nuanced and contextdependent manner (Shade, 2017).

Based on plant height, fruit weight and fruit yield, tested melon genotypes behaved significantly similar as the commercial melon cultivar "Star plus" even though small increase in fruit yield was observed for some genotypes such as H41, H13, H52 and H17. However, no significant variation was noted between the seven tested snake melon genotypes based on plant height and the average fruit weight whereas the total fruit yield per plant significantly varied upon the seven snake melon genotypes. Four snake melon genotypes (namely H47, H48, H49 and H50) produced the highest fruit yield par plant. In our finding, rhizosphere microbial analyses revealed the abundance of actinomycetes in most of melon and snake melon genotypes and Pseudomonas spp. in twelve genotypes as compared to control. Microbiome management by the plant can determine the composition of the root microbiome by active secretion of compounds that specifically stimulate or repress members of the microbial community (Doornbos et al., 2012). In fact, actinomycetes represent a high proportion of soil microbial biomass, and appear to be of importance among the microbial flora of the rhizosphere. They were successfully used as biocontrol and plant growth promoting agents for solanaceous, cucurbitaceous, Brassicaceae, Amaranthaceae, Umbelliferous, Asteraceae, Fabaceae, Asparagaceae, and Amaryllidaceae vegetables crops (Chaurasia et al., 2018). Within the genus Pseudomonas, there are members with potential uses and interests in the environmental and agronomical sectors, like pollutant degraders and plant growth-promoting bacteria such as $P$. putida and $P$. fluorescens (Hernández-Montiel et al., 2017; Qessaoui et al., 2019). The funga relative abundance analyses revealed that Aspergillus populations were more abundant followed by those of Penicillium, Trichoderma, and Fusarium. As demonstrated by Hung and Rutgers (2016), Aspergillus spp. are multifaceted fungi that the plant benefits with different manner such as plant growth promotion and protection. Under natural field conditions, soil amendment with T. harzianum enriched compost led to reduced natural infection by $F$. oxysporum $\mathrm{f}$. sp. melonis on melon plants and to improved melon yields (Pascual et al., 2017). The manganese solubilizer fungus like $P$. citrinum has also been commercially explored as biofertilizer (Barman et al., 2017). Srivastava et al. (2011) demonstrated that $F$. pallidoroseum, a saprophytic fungus, plays a significant positive role in plant growth promotion by enhancing shoot dry weight and shoot length of wheat, maize, marigold, okra, moongbean, and brinjal over control. In the present study, a significant enhancement in the total culturable bacteria community isolated from the soil of ten melon genotypes (H0, H3, H5, H7, H11, H19, H26, H32, H37, and H42) and two snake melon genotypes (H46 and H50) has been clearly demonstrated, compared to "Star plus". These genotypes showed higher microbial diversity. This should be considered in future breeding program to select genotypes that are quite able to exploit beneficial indigenous microbia communities. Indeed, Adam et al. (2018) suggest that a possible implication for breeding programs could be the selection of genotypes enriching less enterobacterial pathogens and/or expressing a higher microbial diversity as demonstrated for Cucumber pepo seeds.

\section{CONCLUSION}

Understanding the vast microbial diversity in the rhizosphere and the interactions between microbiota and vegetables will facilitate the development of future strategies for plant growth and protection. Various experiments assess complex plant-microbe interactions in soil-based systems and begin to elucidate how plants protect themselves by shaping the microbial complexity of the rhizosphere. This study clearly demonstrated the significant role of tested genotypes in the variable distribution of microbial community in the rhizosphere leading to differences in growth and yield parameters between genotypes. The variation in the microbia community structure in our studied genotypes might be due to the changes in the composition of their root exudates which need to be more elucidated in further investigations. Furthermore, ten melon genotypes and two snake melon genotypes showed significant increase in the total culturable bacteria compared to control soil sampled from "Star plus" rhizosphere. This investigation can be valorized in order to incorporate plant-associated microbiome in future strategies for Cucumis melo breeding programs. Indeed a complementary breeding strategy based on genotypes holobiont, which microbes are one of the direct targets of the selection process, will help to achieve a desired plant phenotype. Integrating the knowledge on multifunctional interactions between crop plants and microbes in future agricultural systems and plant breeding will eventually lead to sustainable solutions to reduce the threat imposed by soil-borne pathogens.

Acknowledgements: This work was funded by the Ministry of Higher Education and Scientific Research of Tunisia through the funding allocated to the research unit UR13AGR09-Integrated Horticultural Production in the Tunisian Centre-East, Regional Research Centre on Horticulture and Organic Agriculture of ChottMariem, Tunisia.

\section{REFERENCES}

Adam, E., Bernhart, M., Müller, H., Winkler, J., \& Berg, G. (2018). The Cucurbita pepo seed microbiome: genotype-specific composition and implications for breeding. Plant and Soil, 422, 35-49. https://doi.org/10.1007/s11104-016-3113-9 Aime, S., Alabouvette, C., Steinburg, C., \& Olivain, C. (2013). The endophytic strain Fusarium oxysporum Fo47: a good candidate for priming the defense responses in tomato roots. Molecular and Plant-Microbe Interaction, 26,918-926. Aira, M., Gómez-Brandón, M., Lazcano, C., Bååth, E., \& Domínguez, J. (2010). Plant genotype strongly modifies the structure and growth of maize rhizosphere microbial communities. Soil Biology and Biochemistry, 42, 2276-228. https://doi.org/10.1016/j.soilbio.2010.08.029

Appuhn, A., \& Joergensen, R. G. (2006). Microbial colonisation of roots as a function of plant species. Soil Biology and Biochemistry, 38, 1040-1051. https://doi.org/10.1016/j.soilbio.2005.09.002

Bakker, M. G., Manter, D. K., Sheflin, A. M., Weit, T. L., \& Vivanco, J. M. (2012). Harnessing the rhizosphere microbiome through plant breeding and agricultura management. Plant and Soil, 360, 1-13.

Balasubramanian, N., Priya, V. T., Shanmugaiah, V., \& Lalithakumari, D. (2014) Effect of improved Trichoderma fusants and their parent strains in control of sheath blight of rice and wilt of tomato. Journal of Plant Disease and Protection, 121,71-78.

Barman, M., Paul, S., Choudhury, A. G., Roy, P., \& Sen J. (2017). Biofertilizer as prospective input for sustainable agriculture in India. International Journal of Current Microbiology and Applied Sciences, 6 (11), 1177-1186. https://doi.org/10.20546/ijcmas.2017.611.141

Barnett, H. L., \& Hunter, B. B. (1987). Illustrated genera of imperfect fungi. New York: MacMillan, Publishing Company.

Berendsen, R. L., Pieterse, C. M. J., \& Bakker, P. A. H. M. (2012). The rhizosphere microbiome and plant health. Trends in Plant Science, 17 (8), 478-486 https://doi.org/10.1016/j.tplants.2012.04.001

Berg, G., Köberl, M., Rybakova ,D., Muller, H., Grosch, R., \& Smalla, K. (2017) Plant microbial diversity is suggested as the key to future biocontrol and health $\begin{array}{llll}\text { trends. } & \text { FEMS } & \text { Microbiology } & \text { Ecology, }\end{array}$ https://doi.org/10.1093/femsec/fix050

Bergand, G., \& Smalla, K. (2009). Plant species and soil type cooperatively shape the structure and function of microbial communities in the rhizosphere. FEMS Microbiology and Ecology, 68 (1), 1-13. https://doi.org/10.1111/j.15746941.2009.00654.x

Bulgarelli, D., Rott, M., Schlaeppi, K., Ver, L., van Themaat, E., Ahmadinejad, N., Assenza F., Rauf, P., Huettel, B., Reinhardt, R., Schmelzer, E. et al. (2012) Revealing structure and assembly cues for Arabidopsis root-inhabiting bacterial microbiota. Nature, 488 (7409), 91-95. https://doi.org/10.1038/nature11336

Cardinale, M., Grube, M., Erlacher, A., Quehenberger, J., \& Berg, G. (2015) Bacterial networks and co-occurrence relationships in the lettuce root microbiota Environmental Microbiology, 17 (1), 239-252. https://doi.org/10.1111/1462$\underline{2920.12686}$

Carelli, M., Gnocchi, S., Fancelli, S., Mengoni, A., Paffetti, D., Scotti, C., \& Bazzicalupo, M. (2000). Genetic diversity and dynamics of Sinorhizobium mliloti populations nodulating different alfaalfa cultivars in Italian soils. Applied Environmental Microbiology, 66 (11), 4785-4789.

Chaurasia, A., Meena, B.R., Tripathi, A.N., Pandey, K.K., Rai, A.B., \& Singh, B. (2018). Actinomycetes: an unexplored microorganisms for plant growth promotion and biocontrol in vegetable crops. World Journal of Microbiology and Biotechnology, 34, 132-147. https://doi.org/10.1007/s11274-018-2517-5

Chikh-Rouhou, H., Ben Belgacem, A. M., \& Sta-Baba, R. (2017). Performance of hybrids, their parents and heterosis respect to agronomic traits in melon landraces. Revue des Régions Arides, 43, 153-157.

Chikh-Rouhou, H., Garcés-Claver, A., González, V., Sta-Baba, R., \& DaamiRemadi, M. (2018). Screening for resistance to race 1 of Fusarium oxyporum $\mathrm{f}$. sp. melonis in Tunisian melon cultivars using molecular markers. Communication in Agricultural and Applied Biological Sciences, 83, 87-92.

Chikh-Rouhou, H., Tlili, I., Ilahy, R., R'him T., \& Sta-Baba, R. (2021). Fruit quality assessment and characterization of melon genotypes. International Journal of Vegetable Science, 27, 3-19. https://doi.org/10.1080/19315260.2019.1692268 Compant, S., Samad, A., Faist H., \& Sessitsch A. (2019). A review on the plant microbiome: Ecology, functions, and emerging trends in microbial application. Journal of Advanced Research, 19, 29-37. https://doi.org/10.1016/j.jare.2019.03.004

Cordero, O. X., \& Polz, M. F. (2014). Explaining microbial genomic diversity in light of evolutionary ecology. Nature Reviews Microbiology, 12, 263 273.https://doi.org/10.1038/nrmicro3218

Diab E. A., Vilich H. V. G., \& Sikora, R. A. (2001). The use of phospholipid fatty acids (PL-FA) in the determination of rhizosphere specific microbial communities (RSMC) of two wheat cultivars. Plant and Soil, 228, 291-297.

Doornbos, R., van Loon, L. C., \& Bakker, P. A. H. M. (2012). Impact of root exudates and plant defense signaling on bacterial communities in the rhizosphere. Agronomy for Sustainable Development, 32, 227-243. https://doi.org/10.1007/s13593-011-0028-y 
Edwards, J., Johnson, C., Santos-Medellín, C., Lurie, E., Podishetty, N. K., Bhatnagar, S., Eisen J. A., \& Sundaresan, V. (2015). Structure, variation, and assembly of the root associated microbiomes of rice. Proceedings of the National Academy of Sciences, 112 (8), 911-920. https://doi.org/10.1073/pnas.1414592112 Finkel, O. M., Castrillo, G., Paredes, S. H., González, I. S., \& Dangl, J. L. (2017) Understanding and exploiting plant beneficial microbes. Current Opinion in Plant Biology, 38, 155-163.https://doi.org/10.1016/j.pbi.2017.04.018

Gopal, M. \& Gupta, A. (2016) Microbiome selection could spur next-generation plant breeding strategies. Frontiers in Microbiology, 7, 1971-1980. https://doi.org/10.3389/fmicb.2016.01971

Haichar, F. E. Z., Santaella, C., Heulin, T., \& Achouak, W. (2014). Root exudates mediated interaction belowground. Soil Biology and Biochemistry, 77, 69-80.

Hernández-Montiel, L.G., Chiquito-Contreras, C.J., Murillo-Amador, B., VidalHernández L., Quiñones-Aguilar E.E., \& Chiquito-Contreras, R.G. (2017) Efficiency of two inoculation methods of Pseudomonas putida on growth and yield of tomato plants. Journal of Soil Science and Plant Nutrition, 17 (4), 1003-1012. http://dx.doi.org/10.4067/S0718-95162017000400012

Hung, L., \& Lee Rutgers, S. (2016). Application of Aspergillus in plant growth promotion. New and future developments in microbial biotechnology and bioengineering. In: Gupta, V. K. (Ed.), Aspergillus system properties and applications. Elsevier, 223-227.

Kang, S. H., \& Mills, A. L. (2004). Soil microbial community structure changes following disturbance of the overlying plant community. Soil Sciences, 169, 55 65.

Larkin, R. P., \& Honeycutt, C.W. (2006). Effect of different 3-year cropping systems on soil microbial communities and Rhizoctonia diseases of potato. Phytopathology, 96 (1), 69-79. https://doi.org/10.1094/PHYTO-96-0068

Lundberg, D. S., Lebeis, S. L., Paredes, S. H., Yourstone, S., Gehring, J., Malfatti, S., Tremblay, J., Engelbrektson, A., Kunin, V., Del Rio, T. G., et al. (2012) Defining the core Arabidopsis thaliana root microbiome. Nature, 488 (7409), 8690. https://doi.org/10.1038/nature11237

Marques, J.M., da Silva, T.F., Vollu, R.E., Blank, A.F., Ding, G.C., Seldin, L., Smalla, K. (2014). Plant age and genotype affect the bacterial community composition in the tuber rhizosphere of field-grown sweet potato plants. FEMS Microbiology Ecology, 88, 424-435. https://doi.org/10.1111/1574-6941.12313

Marschner, P., Solaiman, Z., \& Rengel, Z. (2007). Brassica genotypes differ in growth, phosphorus, uptake and rhizosphere properties under P-limiting conditions. Soil Biology and Biochemistry, 39 (1), 87-98. https://doi.org/10.1016/j.soilbio.2006.06.014

Merbach, W., Mirus, E., Knof, G., Remus, R., Ruppel, S., et al. (1999). Release of carbon and nitrogen compounds by plant roots and their possible ecological importance. Journal of plant Nutrition and Soil Sciences, 162, 373-383.

Nallanchakravarthula, S., Mahmood, S., Alström, S., \& Finlay, R. D. (2014) Influence of soil type, cultivar and Verticillium dahliae on the structure of the root and rhizosphere soil fungal microbiome of strawberry. Plos One, 9 (10), 1-10. https://doi.org/10.1371/journal.pone.0111455

Pascual, J. A., Bernal-Vicente, A., Martinez-Medina, A., Ros, M., \& Sánchez, C. (2017). Biostimulant and suppressive effect of Trichoderma harzianum enriched compost for melon cultivation from greenhouse nursery to field production. ISHS Acta Horticulturae, 1164. http://doi.org/10.17660/ActaHortic.2017.1164.29

Qessaoui, R., Bouharroud, R., Furze, J.N., El Aalaoui, M., Akroud, H., Amarraque A., Van Vaerenbergh, J., Tahzima, R., Mayad, E.H, \& Chebil, B (2019). Applications of new rhizobacteria Pseudomonas isolates in agroecology via fundamental processes complementing plant growth. Scientific Reports, 9 (12832), 1-10. https://doi.org/10.1038/s41598-019-49216-8

Radhakrishnan, R., Shim, K. B., Lee, B., Hwang, C. D., Pae, S. B., Park, C. H., Kim, S. U., Lee, C. K., \& Baek, I. Y. (2013). IAA-producing Penicillium sp. NICS01 triggers plant growth and suppresses Fusarium sp.-induced oxidative stress in Sesame (Sesamum indicum L.). Journal of Microbiology and Biotechnology, 23 (6), 856-863. http://doi.org/10.4014/jmb.1209.09045

Reganold, J. P., Andrews, P. K., Reeve, J. R., Carpenter-Boggs, L., Schadt, C. W., Alldredge, J. R., Ross, C. F., Davies, N. M., \& Zhou, J. (2010). Fruit and soil quality of organic and conventional strawberry agroecosystems. PLOS ONE, 5, 114. https://doi.org/10.1371/journal.pone.0012346

Rengel, Z., \& Marschner, P. (2005). Nutrient availability and management in the rhizosphere: exploiting genotypic differences. New Phytologist, 168 (2), 305-312. https://doi.org/10.1111/j.1469-8137.2005.01558.x

Shade, A. (2017). Diversity is the question, not the answer. ISME Journal, 11, 16. https://doi.org/10.1038/ismej.2016.118

Srivastava, R., Mehta, C. M., \& Sharma, A. K. (2011). Fusarium pallidoroseumA new biofertilizer responsible for enhancing plant growth in different crops. International Research Journal of Microbiology, 2 (6), 192-199.

Timm, C. M., Pelletier, D. A., Jawdy, S. S., Gunter, L. E., Henning, J. A., Engle, N., Aufrecht, J., Gee, E., Nookaew, I., Yang, Z., et al. (2016). Two poplarassociated bacterial isolates induce additive favorable responses in a constructed plant-microbiome system. Frontiers in Plant Science, 7, 110. https://doi.org/10.3389/fpls.2016.00497
Trivedi, P., Leach, J. E., Tringe, S. G., Sa, T., \& Singh, B. K. (2020). Plantmicrobiome interactions: from community assembly to plant health. Nature Reviews Micrtobiology, 18, 607-621. https://doi.org/10.1038/s41579-020-0412-1 Vanoli, M., Grassi, M., Bucheri, M., \& Rizzolo, A. (2015). Influence of edible coating on postharvest physiology and quality of Honeydew melon fruit (Cucumis melo L. inodorus). Advances in Horticultural Sciences, 29 (2-3), 65-74 https://doi.org/10.13128/ahs-22683

Wei, Z., \& Jousset, A. (2017). Plant Breeding Goes Microbial. Trends in Plant Science, 22 (7), 558-558. https://doi.org/10.1013/j.tplants.2017.05.009

Wei, Z., Yang, T., Friman, V. P., Xu, Y., Shen, Q., \& Jousset, A. (2015). Trophic network architecture of root-associated bacterial communities determines pathogen invasion and plant health. Nature Communications, 6, 8413-8421.

Weidner, S., Koller, R., Latz, E., Kowalchuk, G., Bonkowski, M., Scheu, S., \& Jousset, A. (2015). Bacterial diversity amplifies nutrient-based plant-soil feedbacks. Functional Ecology, 29, 1341-1349. https://doi.org/10.1111/13652435.12445

Weinert, N., Piceno, Y. Ding, G. C., Meincke, R., Heuer, H., Berg, G., Schloter, M., Andersen, G., \& Smalla, K. (2011). PhyloChip hybridization uncovered an enormous bacterial diversity in the rhizosphere of different potato cultivars: many common and few cultivar-dependent taxa. FEMS Microbiology and Ecology, 75 (3), 497-506. https://doi.org/10.1111/j.1574-6941.2010.01025.x

Wille, L., Messmer, M. M., Studer, B. \& Hohmann P. (2018). Insights to plantmicrobe interactions provide opportunities to improve resistance breeding against root diseases in grain legumes. Plant, Cell \& Environment, 42 (1), 20-40.

Wissuwa, M., Mazzola, M., \& Picard, C. (2008). Novel approaches in plant breeding for rhizosphere-related traits. Plant and Soil, 321, 409-430. https://doi.org/10.1007/s11104-008-9693-2

Wu, F. Z., Han, X., \& Wang, X. Z. (2006). Allelopathic effect of root exudates from cucumber cultivars on Fusarium oxysporum. Allelopathy Journal, 18, 163 172

Yang, H., Li, J., Xiao, Y., Gu, Y., Liu, H., Liang, Y., Liu, X., Hu, J., Meng, D., \& Yin, H. (2017). An integrated insight into the relationship between soil microbial community and Tobacco bacterial wilt disease. Frontiers in Microbiology, 8 , 2179-2189. https://doi.org/10.3389/fmicb.2017.02179

Yao, H., \& Wu, F. (2010). Soil microbial community structure in cucumber rhizosphere of different resistance cultivars to Fusarium wilt. FEMS Microbiology and Ecology, 72, 456-463. https://doi.org/10.1111/j.1574-6941.2010.00859.x

Zamioudis, C., \& Pieterse, C. M. J. (2012). Modulation of host immunity by beneficial microbes. Molecular Plant Microbe Interactions, 25 (2), 139-150. https://doi.org/10.1094/MPMI-06-11-0179 